Andrew C. S. Peacock*

\title{
History, piety and factional politics in the Arabic chronicle of the Maldives: Ḥasan Tāj al-Dīn's Ta'rīkh and its continuations
}

https://doi.org/10.1515/asia-2020-0015

Abstract: The Arabic chronicle (Ta'rīkh) of the Maldives composed by the qadi Hasan Tāj al-Dīn (d. 1139/1727) and continued by his nephew Muhammad Muhibb al-Dīn (1118/1706-1199/1785) and his grandson Ibrāhīm Sirāj al-Dīn (d. after 1243/ 1827) is major but unexploited source for not just Maldivian but also Indian Ocean history more broadly. Covering Maldivian history from the purported date of the islands' conversion to Islam in 548/1143, the Ta'rikh is also imbued with a specific pious and ethical agenda. It seeks to situate the Maldives in the broader context of Islamic history stretching back to the Rāshidūn Caliphs, while using the past to impart ethical lessons to its audience, ostensibly the Maldivian sultans. However, its authors were also deeply involved in the Maldives' tumultuous political life, and their presentation of events is also influenced by their own personal experiences and factional affiliations. This article explores the pious, ethical and political agenda of the Ta'rikh.

Keywords: Maldives, Arabic chronicles, Ḥasan Tāj al-Dīn, Ta'rīkh Islām Dībā Mahal, history of Indian Ocean, Muslim commercial and religious networks

The history of the Indian Ocean world in the early modern period is usually written on the basis of European sources. ${ }^{1}$ Even in areas where there is a strong indigenous tradition of historiography such as India or Java, these chronicles seem to look to the courts of the interior rather than outwards to the maritime world and its interregional connections, although doubtless more could be done to exploit them

1 See for example the classic studies of Das Gupta 1979, Reid 1988, Reid 1993, Barendse 2002.

*Corresponding author: Andrew C. S. Peacock, University of St Andrews, School of History, St Katharine’s Lodge, The Scores, St Andrews, KY16 9BA, UK, E-mail: acsp@st-andrews.ac.uk 
to the full. ${ }^{2}$ An important exception to this is the Arabic-language history of the Maldive islands, entitled by its modern editor the Ta'rīkh Islām Dībā Mahal, ${ }^{3}$ composed in the eighteenth century by a local religious scholar, Qadi Ḥasan Tāj alDīn, who died in 1139/1727. Although a critical edition of the text was published by Hikoichi Yajima in Tokyo in 1982, it is more commonly cited on the basis of the brief English summary by H.C.P. Bell, the eminent historian of the Maldives, first published posthumously in $1940 .{ }^{4}$ As such, it is usually treated, by the rather few scholars who have used it, as a mine for dates and "facts", 5 perhaps inevitably given the absence of other narrative sources for much of Maldivian history. The text certainly deserves to be better known, for the Ta'rīkh has a broader significance as it frequently mentions the archipelago's links to India, Southeast Asia, and the Middle East, providing insights into the ways in which Muslim commercial and religious networks connected the Indian Ocean world.

Yet any reader of the Ta'rik $k$ must take account of the author's agenda, which has not yet been subjected to study. The Ta'rīkh is a highly complex document, despite literary activity in Arabic otherwise being largely unattested in the Maldives (although, as we shall see, this may reflect modern research rather than the historical reality). It is profoundly influenced by its author's own religious proclivities, and by his vision of the Maldives not just as part of a wider contemporary Islamic world stretching across the Indian Ocean, but as taking its place in a broader narrative of Islamic history. It is at least equally a work of advice literature, aimed at showing the rulers of the Maldives how to act as a Muslim king should, and this ethico-religious agenda permeates the text. Finally, the author's own career as a senior member of the Maldivian political establishment also shaped the text in fundamental, if sometimes obscure, ways. These aspects form the subject of this study, which aims to provide a more sophisticated basis for the interpretation of this crucial document for Maldivian and Indian Ocean history.

2 Thus few chronicles of the Deccan or Gujarat, for example, have much to say about the broader maritime world to which these regions belonged. Indeed, even the indigenous historiography of a predominantly maritime people such as the Makassarese focuses more upon internal politics than their oceanic connections. See Cummings 2010. One partial exception is the Arabic chronicle tradition of Hadramawt, in which works like the Ta'rikh al-Shihr do present an important perspective on Portuguese activities in the sixteenth century but remain surprisingly under-used despite their availability in abridged English translation; see Serjeant 1963.

3 This is properly the title of only one section of the text; see further the discussion of the structure of the Ta'rikh below.

4 Bell 2002: 18-42, 201-204.

5 See for example its treatment by Maloney 2013. 


\section{The Ta'rīkh in context}

As far as we know, no tradition of Arabic historical writing existed in the Maldives before Hasan Tāj al-Dīn composed his chronicle at the request of Sultan Muhammad 'Imād al-Dīn (r. 1116/1701-1133/1720). The work comprises two main sections, the first covering the history of the Muslim community from the time of the Prophet to down to the conversion of the Maldives to Islam in 548/1153 in the reign of the Caliph al-Muqtafî, and a second one focussing on Maldivian history up to Hasan Tãj al-Dīn's own time. After the author's death in 1139/1727, it was continued by his nephew Muhammad Muhibb al-Dīn and his grandson Ibrāhīm Sirāj al-Dīn. Muhammad Muhibb al-Dīn's contribution brings the chronicle from 1138/1726 to $1171 / 1758$, and covers some ten pages in the manuscript, while the substantial section written by Ibrāhìm Sirāj al-Dīn deals with the period from the death of Sultan Ibrāhìm Iskandar in 1163/1750 down to 1243/1827. The reason for the overlap between $1163 / 1750$ and $1171 / 1758$, as we shall see, is related to the contentious role of Hasan Tāj al-Dīn's descendants in Maldivian history.

Four manuscripts of the Arabic text have been identified, although one of these, originally consulted by Bell in his classic work on Maldivian history, was reported lost by Yajima and other scholars in the second half of the twentieth century who sought it out. ${ }^{6}$ Moreover, the whereabouts of the three Arabic copies seen in Malé by Yajima in 1981 is currently unclear. ${ }^{7}$ In addition to these Arabic manuscripts, Yajima refers to two manuscripts of a Dhivehi version of the chronicle in Thaana script. ${ }^{8}$ The relationship of the Dhivehi and Arabic texts must be a subject for future research, although it is clear that the Arabic Ta'rikh was originally composed in that language and is not a translation. It seems likely that in fact the Dhivehi version mentioned by Yajima is the same historical chronicle referred to as Radavali by Bell. The latter saw copies written in the modern Thaana and older Dives Akuru script, remarking somewhat delphically that they "confirm, and here and therefore usefully supplement the accepted narrative of 'the State Chronicle,' the Arabic Tarikh, to which they occupy the same relationship as the Sinhalese Rájáwali to the 'Mahávansa' or Great History of Ceylon."9 In fact, the relationship between the various Sinhalese chronicles of the seventeenth century, which were later entitled Rajawali, and the Pali Mahavamsa, which was composed in the fifth century AD, is by no means straightforward. They were aimed at distinct

6 Apparently this manuscript was presented to the Ceylon Government and taken to Colombo; see Bell 2002: 201; two pages from this lost manuscript are reproduced in Bell 2002, Plate P.

7 Pers. comm. Michael Feener.

8 Yajima 1988: 72.

9 Bell 2002: 198. 
audiences, and written in very different periods, even if the Sinhalese texts may draw in places on the Pali ones, while at the same time on occasion deliberately ignoring information in the latter for political reasons. ${ }^{10}$

Thus Bell's comparison with Lankan historiography, which is doubtless inspired by the existence of two parallel chronicle traditions in a "classical" or supranational language on the one hand and a local vernacular on the other, sheds little light on the Maldivian texts. Yet it is likely that information on early Muslim rulers in the Ta'rikh, which is highly schematic, derives from king-lists in Dhivehi such as the Radavali. The keeping of such records may stretch back to a pre-Islamic tradition of historical writing, possibly supported by Buddhist rulers and monks, given the well attested promotion of historical writing in Buddhist monasteries in Sri Lanka, which has numerous affinities with the Maldives. ${ }^{11}$ Maldivian copper plate inscriptions (lomāfānu) from the twelfth to fourteenth centuries sometimes contain historical narratives. However, neither Hasan Tāj al-Dīn nor his continuators mention any written sources at their disposal for information on Maldivian history. On the rare occasions where we can check the Ta'rīkh against an independent source, there are clear discrepancies in chronology. As Yajima noted, the hajj of sultan Hasan b. Abī Bakr, dated by Hasan Tāj al-Dīn to c. 871-2/1467, is also mentioned in an Arabic source by al-Jazīrī (d. 977/1569-70) as having occurred in 838/1434-5. ${ }^{12}$ There are even discrepancies between dates given in the Ta'rīkh and the epigraphic record for events to which Hasan Tāj al-Dīn was an eyewitness. ${ }^{13}$ Perhaps most seriously, the Islamisation of the Maldives, dated by the Ta'rikk to $548 / 1143$ and the reign of Sultan Muhammad, is put by the near contemporary evidence of lomāfānu to some 50 years later, to the reign of a king Gadanaadheethiya (Gaghanādītya) who does not appear in either the Ta'rīkh or those Radavali summarised by Bell. ${ }^{14}$ While the onomastic difference might be interpreted as one being the ruler's Muslim name and the other his earlier Sanskrit one, the discrepancy in chronology is harder to explain. However, the date of 548 for the conversion also appears on a restoration inscription on the Friday mosque of Malé (Hukuru Miskit) which is itself dated 738/1337. ${ }^{15}$ This indicates that Hasan Tāj alDīn was following an established local historical tradition, even if its accuracy may be questionable.

10 Obeyesekere 2019: 249-263, 275-285.

11 Obeyesekere 2019, and Thapar 2013: 414-441.

12 Yajima 1988: 76; Ḥasan Tāj al-Dīn 1982: 11; al-Jazīrī 2002, vol. I, 451.

13 Bell 2002: 176; also Bell 2002: 41 (notes) for a similar discrepancy in Ibrāhīm Sirāj al-Dīn's section.

14 Feener 2020; Gippert 2003; Bell 2002: 19.

15 Kalus/Guillot 2005: 27-40. 
While neither these chronological difficulties nor the thorny question of the Islamisation of the Maldives can be resolved here, Hasan Tāj al-Dīn's choice of Arabic for his historical work deserves some comment. The principal language of administration in the Maldives after the coming of Islam remained Dhivehi, in which almost all surviving waqf documents are made (although many have Arabic exordia), ${ }^{16}$ but inscriptions on mosques were sometimes in Arabic. ${ }^{17}$ Moreover, the choice of Arabic for a historical text was an unusual one in the broader Indian Ocean context, despite its status as a transregional language of both religion and commerce. There are only a handful of parallels outside of Arabic-speaking parts of the Ocean littoral. The closest is sixteenth century Malabar, a region with which the Maldives had close links, where five brief texts documenting the jihad against the Portuguese were composed, three of them in verse. ${ }^{18}$ However, this did not lead to any more general attempt to write the history of the region in Arabic, and although these texts do contain historical information, they are very different in character to the Maldivian Ta'rīkh with its continuous narrative stretching from the coming of Islam to the nineteenth century. Otherwise, the only substantial Arabic historical text composed in India that has been uncovered to date is Ulughkhānī's sixteenth century history of Gujarat, Zafar al-Wālih. ${ }^{19}$ Further afield, there was some tradition of writing Arabic city chronicles on the East African littoral, which later was supplemented and supplanted by a Swahili one. In the mid-nineteenth century, an Arabic history of the Comoros was composed, also by a qadi with eminent political connections. $^{20}$ Yet Arabic was never used for historiography in Southeast Asia, where, after the penetration of Islam, local chronicles employed Malay or other regional languages such as Javanese. There was of course a vigorous tradition of historical writing, including both dynastic and local histories, in Arabia, and especially in the holy cities of Mecca and Medina, but also in Yemen, including Hadramawt. ${ }^{21}$ While the Ta'rīkh's choice of Arabic makes it somewhat anomalous in the context of Indian Ocean historiographical production, its authors were

16 For examples of these documents see Bell 2002; Gippert 2003; and the two waqf documents reproduced at R. Michael Feener (ed.). 2018-2020. Maldives Heritage Survey, https:// maldivesheritage.oxcis.ac.uk/index.php/manuscript-viewer/waqf-endowments/mle-arc-ms9-f0-

111/ and at https://maldivesheritage.oxcis.ac.uk/index.php/manuscript-viewer/waqf-endowments/ gni-mad-ms1-karayye-waqfiyya/ (last accessed 17 May 2020).

17 Kalus/Guillot 2005.

18 Kouria 2017: 31-41; Prange 2018: 139-154; more generally on Arabic in Malabar see Prange 2018: 107-120.

19 See Ahmad 1946 for an overview of Arabic in India.

20 Rotter 1976.

21 Al-Hayla 1994; Serjeant 1963. 
doubtless influenced by this Arabian tradition, given their close ties to the Hijaz and Hadramawt. ${ }^{22}$

If Arabic historical works were rarely composed in the Indian Ocean world outside its Arabophone littoral, the evidence of the Ta'rikk suggests the existence of a flourishing Arabic literary culture in the eighteenth century Maldives of which few traces remain. ${ }^{23}$ Muhammad Muhibb al-Dīn informs us that Hasan Tāj al-Dīn wrote "numerous compositions (tașānîf) on hadith, jurisprudence (fiqh), principles of jurisprudence ( $u s ̦ u \bar{l}$ ), biography (siyar), history (ta'rīkh) and the esoteric (daqā'iq)", ${ }^{24}$ although none of these seems to have survived. Hasan Tãj al-Dīn also cites two Arabic poems of his own composition, a verse chronogram giving the date of death of Sultan Muhammad 'Imād al-Dīn in 1133/1720 which was inscribed on the dome over his tomb, and some verses from a panegyric qasida in praise of that sultan's successor, Sultan Ibrāhīm Iskandar II. ${ }^{25}$ It seems that as well as his continuation of the Ta'rīkh, Muhammad Muhibb

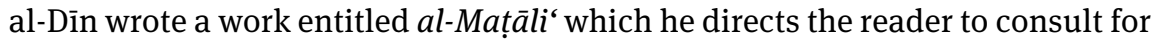
further details of Hasan Tāj al-Dīn's biography (tarjama) ${ }^{26}$ Possibly, then, this was some sort of biographical dictionary. Muhammad Muhibb al-Dīn's father, Husayn Jamāl al-Dīn, was also the author of three different mawlids, works celebrating the Prophet's birthday, entitled Tanwīr al-Qulūb, al-Mi'rāj and Badī‘ al-Anwār, ${ }^{27}$ while Muhammad Muhibb al-Dīn cites 16 lines of an Arabic marthiyya of his own composition lamenting his father's death. ${ }^{28}$ How wide the audience for such works was may be debated; on occasion Hasan Tāj al-Dīn

22 See Forbes 1981.

23 The Maldives Heritage Survey has brought to light a number of manuscripts from across the archipelago; however, most of these are in Dhivehi. The most significant Arabic manuscripts published by them at the time of writing are a 30-volume Qur'an from Hirigalu Miskiyy in Ihavandhoo (Haa Alif Atoll) and two large-format Mi 'rāj manuscripts from Utheemu Palace (Haa Alif Atoll). The comparative paucity of evidence of such texts may be related to the changing religious environment of the Maldives in the late twentieth century, with practices such as the celebration of the Prophet's birthday increasingly abandoned. However, further discoveries are expected to be published by the project website in due course, and they may well revise the picture painted here. See R.M. Feener 2018-2020 (ed.), Maldives Heritage Survey https://maldivesheritage.oxcis.ac.uk/, last accessed 17 May 2020.

24 Ḥasan Tāj al-Dīn 1982: 74. The term daqã $i q$ is ambiguous, as it can mean "minutes”, but also "minutiae" or "subtelties" and is in the latter sense applied to works on a vast range of topics, from fiqh to the occult. On its own, however, it seems most likely to suggest in some sense esoteric knowledge, although this is very much a provisional translation.

25 Ḥasan Tāj al-Dīn 1982: 70, 71.

26 Ḥasan Tāj al-Dīn 1982: 74.

27 Ḥasan Tāj al-Dīn 1982: 81.

28 Ḥasan Tāj al-Dīn 1982: 81-82. 
impugns the abilities at Arabic of even members of the ulama, ${ }^{29}$ although this may reflect his personal enmities more than the reality. On the other hand, a European visitor to the Maldives in 1682 claimed that the "gentry" spoke Arabic and Hindustani, suggesting a much broader diffusion of the language beyond circles of religious specialists. ${ }^{30}$ At any rate, it is evident that Arabic literary culture in the eighteenth century Maldives covered a variety of genres, including history and poetry, and was thus not exclusively restricted to religious purposes.

\section{The chronicler Ḥasan Tāj al-Dīn and Maldivian history}

Muhammad Muhibb al-Dīn provides a brief biography of his uncle, the author of the Ta'rìkh, at the start of his continuation (dhayl). He writes that Hasan Tãj al-Dìn was born in Gan (Gamm) island in Haddhunmathi (Laamu) Atoll in 1072/1661-2, son of the faqīh Mạ̣mūd b. Mūsā al-Qammawī (the nisba al-Qammawī refers to Gan), dying in Rajab 1139/February 1727 aged sixty seven. ${ }^{31}$ Apart from this he gives details of Ḥasan Tāj al-Dīn's shaykhs, who comprised both local scholars such as a certain shaykh 'İsā who died in Gan, and several Meccan shaykhs, including Sālim, son of the noted hadith transmitter 'Abdallāh al-Bașrī. Hasan Tāj al-Dīn was also a devotee of the Muhammad Shams al-Dīn b. 'Abd al-Razzāq, an itinerant Syrian holy man of the Qadiri Sufi order who preached an austere form of Islam and briefly ruled as sultan of the Maldives in $1103 / 1692 .^{32}$

Hasan Tāj al-Dīn also frequently refers to himself in the third person in his work, which allows us to fill out some details of his career, including these sojourns in the Hijaz. He was student of the khațīb Muhammad Sirāj al-Dīn, ${ }^{33}$ the position of khatîib, being, alongside qadi, of the two chief religious posts in the Maldives, appointed by the Sultan. Both khațībs and qadis were intimately involved in political life, which was dominated by intense factional rivalry between various aristocratic clans (boduy), who competed for power and the office of sultan (Dhivehi radun). ${ }^{34}$ Similarly, the khațībs and qadis seem to have been drawn from a limited number of families who formed effectively hereditary

29 Ḥasan Tāj al-Dīn 1982: 52.

30 Maloney 2013: 118.

31 Ḥasan Tāj al-Dīn 1982: 73-74.

32 See Peacock 2018 for a detailed discussion of this episode.

33 Ḥasan Tāj al-Dīn 1982: 39.

34 Nasheed 2003. 
dynasties, ${ }^{35}$ and Muhammad Sirāj al-Dīn's father had held the post of qadi during the reign of Sultan Ibrāhìm Iskandar (1058/1648-1098/1687). ${ }^{36}$ On the latter's demise, his concubine (umm walad) Mariyam seized power, according to Hasan Tāj al-Dīn persecuting men of learning as well as leading an immoral lifestyle. Ḥasan Tāj al-Dīn and another of Muhammad Sirāj al-Dīn's pupils fled to Calicut in Malabar, then to the Hijaz; ${ }^{37}$ according to Hasan Tãj al-Dīn, the Maldivian rulers routinely forbade their subjects from undertaking the hajj, meaning the route by Calicut, presumably under the pretence of trade, was regularly employed for this purpose. ${ }^{38}$

In 1102/1691 Hasan Tāj al-Dīn returned from the Hijaz. At this point, we are told, the umm walad wished to let him reside with his shaykh, the khatiib Muhammad Sirāj al-Dīn, but she was dissuaded by a rival of his at court, and instead sent him into exile in Gan, with instructions that he not be able to leave even to visit the next island - an unusually harsh sentence by local standards. However, Mariyam's death shortly afterwards as the result of a gunpowder explosion in a ship she was on changed the political scene. The khațīb Muhammad Sirāj al-Dīn presided over an assembly that chose a new ruler, Muhammad Muhyi al-Dīn (r. 1102/1691-1103/1692), whom the chronicler lavishly praises as the most just sultan the Maldives had ever seen since its conversion to Islam. He restored Hasan Tāj al-Dīn to favour, honouring him greatly. ${ }^{39}$

There is much in this account that raises questions in the careful reader. If the umm walad hated ulama, why did she apparently allow the khațīb Muhammad Sirāj al-Dīn to remain in post? Why, indeed, did Ḥasan Tāj al-Dīn feel it safe to return in 1102/1691, and why did Mariyam initially wish to let him live with his shaykh in the capital, if her hatred of the ulama was such? We have no answers to these questions, but their existence underlines the fact that the Ta'rikh cannot be taken at face value: its author was deeply implicated in events he reports, and his portrayal of the principal political figures is unquestionably influenced by his own experiences and relations with them.

Our first clear evidence of Hasan Tãj al-Dīn's role in public life comes during the brief five month reign of the sayyid-sultan Muhammad Shams al-Dìn, who replaced Sultan Muhyi al-Dīn, who had been one of his disciples. A member of the

35 Nasheed 2003: 3-5 observes that the office of chief qadi offered the only possibility for outsiders to participate in the Maldivian power structures dominated by the bodun. However, if this was the case in the nineteenth century, in earlier times evidently the senior ulama formed a similarly closed and hereditary clan, although one which foreigners could sometimes join by virtue of prestigious descent and learning.

36 Ḥasan Tāj al-Dīn 1982: 33.

37 Ḥasan Tāj al-Dīn 1982: 39.

38 Ḥasan Tãj al-Dīn 1982: 43.

39 Ḥasan Tāj al-Dīn 1982: 42, 44. 
Hama branch of the descendants of 'Abd al-Qādir al-Jīlānī, Muhammad Shams alDīn had been educated at the Azhar before travelling to Malabar, Coromandel, Aceh and then to the Maldives, preaching an agenda of religious reform. His activities constitute part of the broader spread of sharia-orientated Sufism in this period, but he had a major political impact on individual societies. In Aceh, numerous members of the elite were attracted to his cause, following the green banner of his saintly ancestor 'Abd al-Qādir al-Jīlānī, and promoting his message of "commanding what is right and condemning what is wrong", while in the Maldives he seems to have exercised a similar widespread appeal by calling for the stricter implementation of sharia and the abolition of "innovations". His pious agenda met with both popular support and, ultimately, the anger of sultan Ibrāhīm Iskandar, who forced him into exile in India. However, Muhammad Shams al-Dīn was able to return during the reign of his disciple Muhyi al-Dìn, whom he succeeded as sultan.

Muhammad Shams al-Dīn is styled a khalifa by Ḥasan Tāj al-Dīn. Certainly, he took the religious side of his office seriously. "He commanded what is right and forbade what is wrong, and abrogated everything that was contrary to sharia....He used to admonish the people every night between the dusk and evening prayers; and after evening prayers he used to teach fiqh, grammar and other sciences to Qadi Muhammad, the khațīb Muhammad Sirāj al-Dīn, and shaykh Hasan Tāj alDīn." "40 The exact title held by Ḥasan Tāj al-Dīn is left ambiguous but he evidently played a prominent role in supporting Muhammad Shams al-Dīn's regime (or at least, that is how he wished to be remembered). The sayyid-sultan appointed him to teach hadith in the congregational mosque in Malé, for which he received a salary in the form of a twice-monthly grant, but he was also given a rather more sinister role:

\footnotetext{
[Muhammad Shams al-Dīn] sent [Ḥasan Tāj al-Dīn] out every Friday along with the assistants of Qadi Muhammad and a group of soldiers to patrol the streets of the town in order to command what is right and forbid what is wrong, to order people to congregate for the prescribed prayers at the beginning of its time [awwal al-awqāt], ${ }^{41}$ to punish anyone who resisted him, and to bring before [Muhammad Shams al-Dīn] anyone who failed to attend the prescribed prayers to be killed by the sword of the brilliant sharia. After three Fridays of patrolling, he did not find anyone who failed to attend the prescribed prayers. ${ }^{42}$
}

40 Ḥasan Tāj al-Dīn 1982: 45.

41 Jurists recommended performing prayers at the beginning of their set times.

42 Ḥasan Tāj al-Dīn 1982: 45. 
On Shams al-Dīn Muhammad's death, the Maldivian theocracy continued with the installation of Qadi Muhammad al-Ḥājj 'Alī as sultan (r. 1103/1692-1112/1701), the khațīb Muhammad Sirāj al-Dīn having refused the role and exiling himself to Haddhunmatthi Atoll where he died shortly afterwards. ${ }^{43}$ Hasan Tāj al-Dīn presided at the oath ceremony on his accession, where the military and the viziers promised their allegiance to the new sultan, and in return he swore not to oppress the people or seize the estates of those who died with heirs. His role suggests Hasan Tãj al-Dīn already held a senior position, and indeed he was formally appointed as qadi by the new sultan in Rabī' I 1104/November 1692, aged thirty two. ${ }^{44}$ During his tenure as qadi, Hasan Tāj al-Dīn continued to uphold stringently the requirements of sharia, with the sultan's full support. He claims to have been the first to ban the enslavement of free men and women in the Maldives, and the first to insist on upholding the right of females to inherit in accordance with sharia. More remarkably, he even succeeded in quelling the fights over women that seem to have bedevilled Maldivian society:

[The sultan] ordered them to be content with the qadi's judgement. Then when the qadi [Ḥasan Tāj al-Dīn] judged that the divinely ordained punishments [ḥudūd], punishments and oaths should be upheld, they ceased their wickedness and wrongdoing [al-fujūr wa'l-fasād] out of shame at being punished in the court of judgement. ${ }^{45}$

Another form of wrongdoing he prevented was the custom of women cutting each other's hair, for this apparently led to them "tearing each other's clothes so that their private parts were exposed to groups of men and women; but none had seen this as wrong before sultan Muhyi al-Dīn came to power; during his reign, before taking office as qadi, Qadi Ḥasan Tāj al-Dīn had prohibited this practice." ${ }^{46}$ During a subsequent period as qadi, in 1117/1705, Hasan Tāj al-Dīn banned the custom of eating sweets at performances of the praise poems on the Prophet's birthday, the Mawlid; later he forbade the distribution of a delicacy of sweetened rice at Ashura. ${ }^{47}$ He seems to have taken particular pride in fixing the correct hours for dawn and evening prayers in the Maldives. ${ }^{48}$ Hasan Tāj al-Dīn thus evidently wished to be remembered for upholding the austere form of Islam propagated by his shaykh, Muhammad Shams al-Dīn.

When Sultan Muhammad al-Ḥājj 'Alī died in 1112/1701, Hasan Tāj al-Dīn presided at his funeral, but soon realised he needed to flee to the Hijaz as his arch

43 Ḥasan Tāj al-Dīn 1982: 46.

44 Ḥasan Tāj al-Dīn 1982: 48.

45 Ḥasan Tāj al-Dīn 1982: 50.

46 Ḥasan Tāj al-Dīn 1982: 50.

47 Ḥasan Tāj al-Dīn 1982: 69.

48 Ḥasan Tāj al-Dīn 1982: 68. 
enemy 'Alī al-Kuredhivaruwi ${ }^{49}$ was appointed qadi by the new sultan 'Alī b. Shāhbandar Ibrāhīm (r. 1112/1701-1113/1701). The Ta'rīkh at this point is filled with bitter invectives against the qadi and the sultan, who sought to persecute Hasan Tāj al-Dīn even in exile, planning to send a message to the Sharif of Mecca informing him that the fugitive had stolen money from the public treasury. The sultan's death after a 10 month reign is depicted as divine retribution. The sultan was briefly replaced by his son Hasan, aged 13 or 14, but the latter was himself swiftly deposed by his cousin, who took the throne as sultan Ibrāhīm Muzhir al-Dìn (r. 1113/1701-1116/1705). This latter restored Ḥasan Tāj al-Dīn to favour, sending a ship to bring him back from exile in the Hijaz. ${ }^{50}$

At this point, Hasan's involvement in Maldivian politics becomes even murkier. The new sultan is praised for building mosques and abolishing uncannonical taxes (mukūs), but Hasan Tāj al-Dīn omits to tell us whether he was reappointed qadi. However, a reference elsewhere in the text to how the adhān times were fixed by the order of Qadi Hasan Tāj al-Dīn in 1114/1702 confirms he did hold the office under Sultan Ibrāhīm Muzhir al-Dīn. ${ }^{51}$ The reason for his reticence is clear, even if his precise involvement in subsequent events is not. In 1115/1704, Ibrāhīm Muzhir al-Dīn set off to perform the pilgrimage to the Hijaz accompanied by a substantial retinue, including, according to one manuscript of the Ta'rikh, Hasan Tãj al-Dīn himself. ${ }^{52}$ Yet the party was beset by disaster on its return. Several members of the royal family fell ill and died in Jeddah, and the sultan himself contracted small-pox. Anxious to return home, they ignored the well-meaning warnings of the governor of Mocha that they had left it too late in the monsoon season to risk the voyage. Just off Socotra, the ship encountered a violent storm that produced "waves as high as mountains", and the party feared they would drown. Eventually, they were washed up in Sindh, where it seems their ship sank, leaving its passengers to save themselves by swimming to shore, only to be robbed by locals. Among the survivors were Sultan Ibrāhīm Muẓhir al-Dīn and Hasan Tāj al-Dīn himself who "wandered barefoot, naked and hungry through the land of Sindh and India", until they reached the port of Surat, where they found a ship to take them back to the Maldives, eventually landing at Manadhoo in Miladhunmadulu Atoll. ${ }^{53}$

49 الكردوي. This is presumably this nisba for either Kuredhivaru or Kuredhdhoo, both in Miladhunmadulu Atoll.

50 Ḥasan Tāj al-Dīn 1982: 52-53.

51 Ḥasan Tāj al-Dīn 1982: 68.

52 Ḥasan Tāj al-Dīn 1982: 54; and 1984: 56, note 3; the reference to Ḥasan Tāj al-Dīn’s presence in the party is only present in Yajima's Manuscript C, described briefly in Hasan Tāj al-Dīn 1982: 3 (English introduction).

53 Ḥasan Tāj al-Dīn 1982: 55-56, 57. 
In his absence the Maldivian people assumed that Ibrāhīm had died, and after a power struggle in Malé, the wazir was installed as ruler by the military with the title Muhammad 'Imād al-Dīn (r. 1116/1704-1133/1720). He thwarted an attempt by Ibrāhīm Muzhir al-Dīn to enter Malé, and the deposed Sultan fled from the internal exile that was imposed on him to seek refuge first in Galle in Sri Lanka, then in India. In circumstances that are opaque, Hasan Tāj al-Dīn somehow managed to switch sides, for two months after his accession Muhammad 'Imād al-Dīn reappointed him qadi. ${ }^{54}$ Meanwhile, Ibrāhīm Muzhir al-Dīn made his way to Calcutta, where he sought Mughal and English support to regain his throne. An English fleet was sent to restore Ibrāhīm to his throne, and Hasan Tāj al-Dīn portrays the ensuing battle as one between Islam and unbelief, and emphasises his role in urging Muhammad 'Imād al-Dīn to do battle against the invaders. ${ }^{55}$ The implication is clearly that by seeking infidel support, the former sultan has lost any shred of legitimacy. Doubtless his change of allegiance to Muhammad 'Imād al-Dīn lies behind Ḥasan Tāj al-Dīn's obfuscation of his role as qadi to Ibrāhīm Muzhir al-Dīn.

As far as we can understand from the Ta'rīkh, Hasan Tāj al-Dīn remained in office as qadi for the rest of Muhammad 'Imād al-Dīn's reign. However, his involvement in controversies was not over. He tells us of the plot around 1127/1715 between the treasurer (al-khäzin al-kabïr) and the sultan's wife Āmina, who were enjoying an adulterous relationship. They tried to remove the sultan's son by another wife, Ibrāhīm, from the line of succession in order to put the treasurer on the throne. They did this by attempting to convince the sultan that people were conspiring to depose him in favour of Ibrāhīm, and as part of their scheming, they tried to poison the sultan's mind against Hasan Tāj al-Dīn. At first the sultan was convinced, but later the truth came out, and the treasurer was exiled to Fuah Mulah Atoll (Fua Mulaku) in the far south of the archipelago. There he was subjected to appalling torture, until in the end Qadi Hasan Tãj al-Dīn interceded for him with the sultan, and had his conditions of exile improved. ${ }^{56}$ Yet no explanation is given for why Hasan Tāj al-Dīn intervened.

The final sultan to be mentioned, albeit briefly, is Ibrāhīm Iskandar II, to whom Hasan Tãj al-Dīn wrote an Arabic panegyric qasida. However, in the prose text of the Ta'rikh, the sultan is criticised for abandoning the company of ulama to devote himself to pleasure, before having a change of heart and returning to a pious lifestyle in the third year of his reign. The final two events recorded in the Ta'rikh authored by Ḥasan Tāj al-Dīn are a fire in the vizier's house in 1137/1724 and the

54 Ḥasan Tāj al-Dīn 1982: 58.

55 Ḥasan Tāj al-Dīn 1982: 60, 64

56 Ḥasan Tāj al-Dīn 1982: 65. 
birth of a daughter to the sultan in the same year. ${ }^{57}$ It seems therefore, that Hasan Tāj al-Dīn stopped writing at this point, two years before his death.

Bell's description of the Ta'rikh as the "State chronicle" of the Maldives is thus somewhat misleading. It is true that Hasan Tãj al-Dīn concentrates on high politics and the lives and deaths of sultans. Yet in many ways the Ta'rīkh is as much about Hasan Tāj al-Dīn and his career as about the history of the Maldives as a whole. In addition, its representation of Maldivian history is strongly influenced by Hasan Tāj al-Dīn's ethical concerns.

\section{The structure and agenda of the Ta'rīkh}

The Ta'rīkh as composed by Ḥasan Tāj al-Dīn is divided into three sections, which are given distinct titles in the original:

Introduction, entitled al-Rutba al-Fākhira fi salțanat al-dunyā wa'l-ākhira, or the Lofty Degree on rulership in this world and the next (pp. 1-6 of Yajima's Manuscript A, the basis of his edition). ${ }^{58}$

History of Prophets and Kings to the reign of the 'Abbasid Caliph al-Muqtafi ( $b \bar{a} b$ fi ta'rikh alanbiy $\bar{a}$ ' wa'l-mursalin) (pp. 8-33, which is preceded by an untitled discussion of the reasons for the work's composition on pp. 6-8)

Islamic history of the Maldives from conversion in al-Muqtafi's reign (548/1154) to the reign of Ibrāhīm Iskandar II (1137/1724) (bāb Ta'rīkh Islām Dībā Mahal) (pp. 33-85)

These are followed by the two continuations by Muhammad Muhibb al-Dīn and Ibrāhīm Sirāj al-Dīn.

Hasan Tāj al-Dīn's pious and political agenda is made quite explicit in the introductory chapter, al-Rutba al-Fākhira fi salțanat al-dunyā wa'l-ākhira, which is almost a separate treatise, although as we will see, its concerns are reflected in the historical parts. This essentially constitutes a condensed mirror for princes, drawing on tropes familiar from classical authors such as al-Ghāzālī's (d. 505/ 1111) famed Nașihat al-Mulūk - and indeed the chapter concludes by referring to itself by this title. ${ }^{59}$ Although it is not entirely clear to what extent the chapter, like the subsequent one, may be largely lifted from earlier works, the several verses of Persian poetry quoted underline its indebtedness to Middle Eastern literary as well

57 Hasan Tāj al-Dīn 1982: 71-72.

58 I refer here to the page numbers of facsimile of manuscript A presented in Hasan Tāj al-Dīn, as the second chapter was omitted by Yajima from the printed text.

59 Hasan Tāj al-Dīn 1982: 7. 
as religious sources. There is one couplet by the famous Sa'dī (d. 689/1291), and, perhaps more surprisingly, a quatrain attributed to the lesser known Bundār-i Rāzī (fourth/tenth century). ${ }^{60}$ However, these verses are cited in the dictionary of poets, the Tadhkirat al-Shu'arā' of Dawlatshāh, composed in 892/1486, which circulated very widely and thus was most likely the source. The existence of these Persian verses may seem surprising, but the Maldives enjoyed very close connections with the Iranian world, with a substantial Persian substratum of vocabulary in the Dhivehi language. The saint who converted the islands to Islam, Yūsuf Shams alDinn, is said to have come from Tabriz, and the first coins minted in the Maldives from the sixteenth century onwards were known as Lari, emulating those of Lar in southern Iran. There may also have been a certain taste for Persian literature in the Maldives as late as the nineteenth century, for the English officers Young and Christopher who visited Malé in 1835 recorded that the Fandiyāru or chief justice "has many Persian manuscripts, but only one could be procured by us". ${ }^{61}$ The pleasure-loving Sultan 'Imād al-Dīn IV (r. 1835-1882) sent Maldivians to Persia to be trained as poets and singers. ${ }^{62}$ However, Hasan Tāj al-Dīn provides an Arabic translation for the verses, indicating he did not expect his audience necessarily to understand them.

Al-Rutba al-Fākhira opens by discussing the necessity of kings; sunna, says the author, decrees the existence of kings and if they did not exist, the world would fall to pieces. At the same time, they must be constantly aware of the next world (ākhira). He describes four classes of sultans:

- Sultans of the next world and poor in this world (salātīn al-ākhira wa-fuqarā', al-duny $\bar{a}$ ), who are "the poor Muslims who patiently endure their poverty".

- Sultans of this world and poor in the next (salātīn al-dunyā wa fuqarā' al$\bar{a} k h i r a$ ), who are "the sultans who followed the path of oppression and tyranny and turned away from the way of justice and equity”.

- Those who have no rulership in this world or the next (lā saltana lahum fìldunyā wa'l-ākhira), who are "the poor who do not patiently endure their poverty, and deny the blessings of their lord (kafarū bi-ni'mat rabbihim)”.

60 Ḥasan Tāj al-Dīn 1982: 4; 6; cf. Sa‘di 1375: 768. The quatrain by Bundār-i Rāzī is somewhat distorted, presumably as copyists could not understand it. It should read

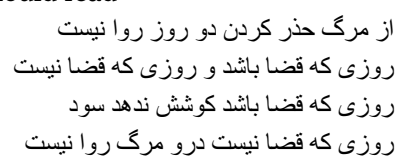

I am very grateful to Saeed Talajooy for identifying the poet. On him see Safa 1989, and Dawlatshah 1901: 42-44.

61 Maloney 2013: 106.

62 Nasheed 2003: 75. 
- Sultans of both this world and the next (salāțin al-dunyā wa'l-ākhira), who are "the [first] four Caliphs and the just kings who follow the former's path and imitate them". 63

Piety and just rulership are thus inextricably linked, and on these depend the sultan's hopes of attaining the next world, which can be achieved by imitating the examples of the Rightly-guided Caliphs. At the same time, rulership has four practical supports: the treasury, the soldiers, the latter's consent, and justice. Hasan Tãj al-Dīn outlines how these can be obtained, before moving onto his main theme, the conduct of sultans (ādāb al-salāțin). Sultans must be strong and courageous, but they must also be the most knowledgeable of men; they will achieve this if at night they spend their time with boon-companions (nudamā') who read for them "histories and biographies of just sultans (al-tawārīkh wa-siyar al-salātīn al-'ädilīn)” which is the way to learn how to be a just king. ${ }^{64}$ During the daytime the sultan should spend his time with ulama, from whom he will acquire knowledge (' $\mathrm{ilm}$ ). The study of history thus is a practical way of learning how to manage the kingdom, and as Hasan later says, one of the main causes of the fall of kingdoms is the sultan's ignorance of reports about it; ${ }^{65}$ but at the same time, its study is also by implication a religious requirement, equal to consorting with ulama.

The second section of the Ta'rikh explains the reasons for its writing. Hasan tells us that one of the kings of the Maldives requested that he compile for him a history of the islands from the coming of Islam. ${ }^{66}$ He does not identify the ruler, but the information that it was Muhammad 'Imād al-Dīn is given by the continuator Ibrāhīm Sirāj al-Dīn. ${ }^{67}$ Hasan adds that he decided to preface his work with "what I have read of the history of Prophets down to the time of our lord Muhammad, the Seal of Prophets, so that it can be an indication of the approach of the Final Hour and the Resurrection of the Dead, and a reminder of death for those who think on it, and an example to whoever considers well.” He expands on this point

For knowledge of history ('ilm al-ta'rikh) comprises reading events that happened, reports of affairs and the circumstances of [our] predecessors which time has preserved, and the events that befell [humankind], in order that man might contemplate the state of the material world $[$ duny $\bar{a}]$, which may turn against him and his sons any moment. ${ }^{68}$

63 Ḥasan Tāj al-Dīn 1982: 1.

64 Ḥasan Tāj al-Dīn 1982: 4.

65 Ḥasan Tāj al-Dīn 1982: 5.

66 Ḥasan Tāj al-Dīn 1982: 8.

67 Ḥasan Tāj al-Dīn 1982: 88. For reasons that are unclear, Yajima (1988: 4) states he composed the Ta'rikh at the behest of this ruler's son, Ibrāhīm Iskandar II (r. 1133/1720-1163/1750).

68 Ḥasan Tāj al-Dīn 1982: 9. 
He should then contemplate all he has acquired in this world and consider how he should leave it behind, and Ḥasan Tāj al-Dīn quotes the verse

Look at those who possessed the entire world, did anything from it accompany them apart from a cotton [burial sheet] and shroud?

Historiography, then, in Hasan Tāj al-Dīn's view, has a specific religious function to force men to contemplate the vanity of worldly existence.

The Ta'rikh then proceeds to the history of prophets and kings down to the reign of the Abbasid Caliph al-Muqtafi, which is entirely omitted in the printed edition, although fortunately Yajima provides a facsimile of his main manuscript. Yet this chapter comprised a substantial section of the original work, some 24 pages out of 85 in Yajima's Manuscript A (excluding the later dhayls), or more than a quarter of the total, although the treatment of the two topics is highly uneven. The Prophets are given short shrift in the initial two pages which list the names and lifespans of those from Adam to Muhammad, but the real focus is on the history of the umma, in particular its leaders the Caliphs. The only source mentioned is a rather confusing reference to the Maghāzi of Ibn Qutayba (d. 276/889), the well known Abbasid author; yet no such work can be found attributed to him. Further, Ibn Qutayba died some two centuries before the conclusion of this part of the text, so even if sections are drawn from a work by this author, he cannot be the source for much of it. In fact, a close comparison reveals that in fact Hasan Tãj al-Dīn's source for Caliphal history is the famous zoological encyclopaedia of the Mamluk author al-Damīīi (d. 808/1405), the Hāayat al-Hayawān. The use of such a source is less surprising than it may appear. The Hayat al-Hayawān was a run-away best seller, and manuscripts of its text can be found as far away as Indonesia. ${ }^{69}$ Its popularity derived in part from the fact that it contained many digressions, making it a convenient encyclopaedia of a wide variety of knowledge. ${ }^{70}$ Al-Damīrī's entry for goose is the occasion for a substantial exposition of early Islamic history as the Caliph 'Alī b. Abī Tâalib encountered geese quaking in his face shortly before his assassination, to support al-Damīri’s idea that every sixth Caliph abdicated or was deposed. ${ }^{71}$ Al-Damīrī, who himself largely relied on Ibn Khallikān (d. 681/1282), is largely copied verbatim by Hasan Tãj al-Dīn, although with some omissions, so the Ta'rīkh's narrative gives the bare bones of Caliphal history.

69 Two eighteenth-century copies formerly belonging to the sultans of Banten in Java are held in the National Library of Indonesia in Jakarta, MSS A 157 and A 158. See Friedrich and van den Berg 1873: 130.

70 De Somogyi 1950.

71 De Somogyi 1950: 42. 
This material is directly relevant to Hasan Tāj al-Dīn's purpose in a number of ways. Al-Damirì's emphasis on the repeated abdication and deposition of later Caliphs would have certainly resonated in the Maldives, which saw numerous sultans unthroned. These parts of the text may thus have implicitly served to legitimise and normalise recent Maldivian political history. It is perhaps no coincidence that Hasan Tāj al-Dīn's own patron, Muhammad 'Imād al-Dīn, who commissioned the Ta'rīkh, had deposed Ibrāhīm Muẓhir al-Dīn, and the chronicler himself had changed sides.

Secondly, in keeping with Hasan Tãj al-Dīn's ethical agenda as laid out in alRutba al-Fākhira, the Caliphs furnish examples of exemplary and condemnable behaviour. For example, while the pious 'Umar b. 'Abd al-'Azīz is held up as a model for his piety, and the text emphasises the public support he enjoyed, ${ }^{72}$ alWalīd b. Yazīd (r. 125/743-126/744) is condemned for wine-drinking and obsession with frivolity, for which he was deposed by the people of Damascus. ${ }^{73}$ Similarly, the 'Abbasid al-Mahdī (r. 158/775-169/785) "was generous, praiseworthy, loving towards his subjects, of fair morals and appearance ... he was noble, fair in appearance, courageous and loved the ulama. He used to summon the ulama and qadis to be brought before him, and had they not been present he would not have wished to hold the court of redress [mazālim] out of respect for them, and much good resulted from that."74 Al-Mahdì's behaviour thus reflects Hasan Tāj al-Dīn's recommendations in al-Rutba al-Fākhira, and is clearly intended to be exemplary.

Thirdly, the section on Caliphal history serves to place the Maldives in the broader sequence of Islamic history. The list of Caliphs comes to an end in the twelfth century with al-Muqtafi, in whose time the Maldives were converted to Islam. The third section of the text now has a much more local focus on the Maldivian rulers, but is extremely uneven in its coverage, focussing on three key episodes: the conversion of the Maldives by the itinerant preacher, Yūsuf Shams alDīn al-Tabrīzī, in 548/1143; the wars of the sixteenth century against the Portuguese; and the turbulent period of the late seventeenth and early eighteenth century through which Hasan Tāj al-Dīn himself lived. A constant theme is the relationship between the Maldivian sultans and the ulama from whom on some occasions the kings were themselves drawn, such as the Qadi Muhammad b. alḤājj 'Alī, who succeeded Muhammad Shams al-Dīn as sultan in 1692 and appointed Hasan al-Dīn qadi for the first time. The qadi-sultan Muhammad is depicted in uniformly positive terms, as "merciful to the weak, severe to

72 Hasan Tāj al-Dīn 1982: facsimile 19.

73 Hasan Tāj al-Dīn 1982: facsimile 21.

74 Ḥasan Tāj al-Dīn 1982: facsimile 22. 
oppressors, and compassionate to the people"; among his achievements were building numerous mosques and restoring waqfs which had previously been confiscated. ${ }^{75}$ There is a correlation between the sultan's attitude towards ulama and how his reign is portrayed, including its commercial aspects. We are told that under Sultan Muhammad b. al-Ḥājj 'Alī prices were low and commerce from India, Aceh and Surat intensified. ${ }^{76}$ Clearly this reflects at least as much an idealised situation as any economic reality.

Hasan Tāj al-Dīn's moralistic purpose occasionally is made quite explicit. For instance, when discussing the exile and torture of the treasurer who had betrayed Sultan Muhammad 'Imād al-Dīn by engaging in relations with his wife and plotting to take the throne for himself, Hasan Tāj al-Dīn comments:

Oh you who are wise, look how the riches and servants he had acquired availed him not, but harmed him because he acquired riches. Thus all wealth which is taken in this wrongful way will not benefit the person who acquired it, but harms its owner and is destroyed with him. It is impossible that riches acquired through the moaning of the sorrowful, and violently seized and plundered from the poor oppressed should benefit the one who plunders them, nor should they profit their owners. How should someone enjoy what he has obtained in this way, which makes its owner weep? Verses:

Illicit riches one day will destroy his family and relatives. ${ }^{77}$

Hasan then records the sickness and death of the treasurer's co-conspirator, Āmina, after a violent illness which confounded the doctors. The story thus functions not just a record of the pair's treachery, but as a morality tale warning against greed and love of material possessions, sins which are swiftly punished by God.

The individual cases of oppressive or praiseworthy sultans - and indeed ulama - have an exemplary function of exhorting the audience to justice and to following the precepts of Islam, while underlining the damage, both material and moral, that results from deviating from the straight path. The framing of the text within a context of salvation and Caliphal history serves to reinforce the Maldives' place in this broader scheme, a point repeatedly reinforced by references to sultans' and ulama's ongoing connections with the sacred land of the Hijaz through the hajj. Throughout the text, at crucial moments, there reappears the figure of the patron saint to the Maldives, Yūsuf Shams al-Dīn al-Tabrīzī, by whose side only the holiest of rulers are buried, such as the exemplary sayyidsultan Muhammad Shams al-Dīn, and at whose grave people and rulers supplicate in times of acute trouble, such as infidel invasion. ${ }^{78}$ In this way the patron

75 Ḥasan Tāj al-Dīn 1982: 47-48.

76 Ḥasan Tāj al-Dīn 1982: 48.

77 Ḥasan Tāj al-Dīn 1982: 67.

78 Ḥasan Tāj al-Dīn 1982: 22, 60. 
saint of the Maldives and the story of the islands' Islamisation is brought into play in later periods. Hasan Tāj al-Dīn's pious agenda is as prominent as his historical one; indeed, it is clear that the author does not really distinguish between the two, ultimately seeing reading and writing historical texts as a religious task, providing moral examples for the reader while reminding him of the vanity of this world.

\section{The descendants of Tāj al-Dīn: family politics and the continuations of the Ta'rīkh}

In addition to their literary activities, the family of Hasan Tāj al-Dīn were closely involved in politics. On Ḥasan Tāj al-Dīn's death, his son, Muhammad Shams alDīn, who seems to have been named after his father's esteemed teacher, took his place as chief qadi, while a few years later in 1153/1740 Hasan's nephew Muhammad [Muhibb al-Dīn] was appointed khațīb. ${ }^{79}$ Hasan's brother and disciple, Muhammad Muhibb al-Dīn's father, Husayn Jamāl al-Dīn, held the position of nā'ib al-saltana from the time of Ibrāhīm Iskandar's father to his death in 1159/ $1746 .{ }^{80}$ This position was then inherited by Muhammad Muhibb al-Dīn. ${ }^{81}$ In other words, eighteenth century Maldivian religious and political life was dominated by this family of religious scholars from Gan. This might be reason enough to explain their interest in chronicling the history of the islands, and ensuring their own role was remembered positively. Yet the political role of some members of the dynasty was highly contentious; as Bell remarks, "Strange irony that the family to whom the Máldive Kingdom is indebted for its 'State Chronicle', should live in history under the stigma of perhaps the greatest act of treachery whichever sullied its not uneventful record". 82

Bell is referring to the involvement of Hasan Tāj al-Dīn's son and successor as qadi in the invasion of 1166/1753 launched by the Ali Raja dynasty of Cannanore. ${ }^{83}$ In this traumatic event, the Malabar forces burned down the royal palace and took captive the sultan, Muhammad 'Imād al-Dīn III, along with his nephew and viziers. ${ }^{84}$ These were all taken back to Cannanore, but what happened next on the

79 Ḥasan Tāj al-Dīn 1982: 77, 79.

80 Hasan Tāj al-Dīn 1982: 74, 80.

81 Ḥasan Tāj al-Dīn 1982: 82.

82 Bell 2002: 202.

83 On the Ali Rajas see Prange 2018: 2002-2005; Mailaparambil 2011.

84 Ḥasan Tãj al-Dīn 1982: 83, 89; Bell 2002: 38 notes that these events are also covered in Dutch records, presumably those held in Colombo. These would repay investigation. 
Maldives was a bone of contention even within Hasan Tāj al-Dīn's family. Muhammad Muhibb al-Dīn records that,

When [the Malabaris] had exiled the sultan from his country and taken him to Cannanore, they swore a deceitful and treacherous oath of allegiance (bay'at al-makr wa'l-khad') to Qadi Muhammad Shams al-Dīn son of the Qadi Hasan Tāj al-Dīn. They stayed loyal to him for some days. Then they took the qadi and his brother khațīb Ahmad Muhyi al-Dīn because they had the impression they were seeking kingship. They tied them up and utterly humiliated them even though both were virtuous scholars. Praise be to Him who makes mighty and contemptible, by God this humiliation only befell them owing to their inclination towards the adornments of this transitory world.

Subsequently, Muhammad Muḥibb al-Dīn reports, Shams al-Dīn and Muhyi al-Dīn were killed by the Malabaris. ${ }^{85}$ The details are reported in a quite different fashion by Ibrāhīm Sirāj al-Dīn, who writes that after exiling 'Imād al-Dīn and his ministers.

The Malabaris who were in the Maldives continued to obey Qadi Muhammad Shams al-Dīn for some time. Then they felt envy towards him and his brother khațib Aḥmad Muhyi al-Dīn and killed them both by drowning ... I wished to avert my pen from the calumnies and slanders that have been said about these two, for they were lengthier and sharper the disasters [that befell us]. ${ }^{86}$

Ibrāhīm Sirāj al-Dīn then quotes the Qur'anic verses, 17:36, 49:6, 49:12, which warn against trusting false news. To this he adds Q. 3:21-22 “Those who disbelieve God's signs and kill the prophets for no cause and kill those men who order justice, inform them of a painful torment. Those are the ones whose works in this world and the next are frustrated, and they have no helpers." The slaughtered qadi and his brother are thus compared to the prophets and righteous doers against whom the Qur'anic pagans fought, and in case the point is missed, Ibrāhīm Sirāj al-Dīn then quotes hadith at length to similar effect.

Even if the basic record of facts is similar, the interpretation given by each author is quite different. Muhammad Muhibb al-Dīn implies that Muhammad Shams al-Dīn and Muhyi al-Dīn had sought worldly power, receiving the bay'a, the oath of allegiance traditionally given to a ruler, and commenting that they met their fate owing to their predilection for worldly vanities (zakhārif al-dunyā al-fāniyya). In contrast, Ibrāhīm Sirāj al-Dīn mentions only that the Malabaris obeyed these two, but omits any reference to a bay' $a$. This could be interpreted simply as the obedience due to religious figures. Meanwhile, far from being men corrupted by this world, Ibrāhīm Sirāj al-Dīn goes to considerable lengths to portray Muhammad Shams

85 Ḥasan Tāj al-Dīn 1982: 84.

86 Ḥasan Tāj al-Dīn 1982: 89. 
al-Dīn and Ahmad Muhyi al-Dīn as martyrs comparable to the ancient prophets. Thus, different axes are being ground by each author. Doubtless we will never fully understand the evidently poisonous family politics at work here, but from Ibrāhīm Sirāj al-Dīn's account it becomes apparent that the direct beneficiary of the murder of Muhammad Shams al-Dīn b. Hasan Tãj al-Dīn was none other than the chronicler Muhammad Muhibb al-Dìn, who was appointed to the position of chief qadi in his stead. ${ }^{87}$ Although the identity of the person who appointed Muhammad Muhibb al-Dīn is left ambiguous behind a third person plural verb "wallaw/they appointed", it is strongly implied that it was the Malabari occupiers, for we are then told that "Qadi Muhammad Muhibb al-Dīn travelled to meet sultan Ali Raja of Cannanore." 88 Meanwhile the Malabari forces plundered and oppressed the Maldivians, who plotted to revolt. The Ali Raja, however, sent reinforcements to the Maldives.

Despite his collaboration with the Ali Raja, Muhammad Muhibb al-Dīn was appointed chief qadi by the new sultan Hasan 'Izz al-Dīn who acceded the throne in 1173/1759; he was, however, dismissed "for no just cause" (bi-ghayr haqq yujawwizu al-'azl bihi) by the sultan while absent on the hajj and replaced with Muhammad Shams al-Dīn b. Tāj al-Dīn's son Ibrāhīm. ${ }^{89}$ On the latter's death in 1182/1768, Muhammad Muhibb al-Dīn was again reappointed as chief qadi by sultan Ḥasan 'Izz al-Dīn's successor, Ghiyāth al-Dīn Iskandar. ${ }^{90}$ Yet Ibrāhīm Sirāj al-Dīn tells us of rumours circulating that Muhammad Muhibb al-Dīn had ordered the murder of Ghiyāth al-Dīn, although he claims not to believe them. ${ }^{91}$ Muhammad Muhibb al-Dīn finally died in in 1199/1785, and the sultan wanted to appoint Ibrāhīm Sirāj al-Dīn's father Muhyi al-Dīn as qadi but was prevented by a palace faction who successfully insisted on the appointment of a pupil of Muhammad Muhibb al-Dīn's, Najm al-Dīn Mūsā, who had cemented his links to his teacher by marrying the latter's daughter. ${ }^{92}$

Thus the family of Hasan Tāj al-Dīn was riven by disputes between two opposing factions (Figure 1). One was descended from his brother Husayn Jamāl alDīn, of which Muhammad Muhibb al-Dīn, the first continuator of the Ta'rìkh was the leading member; the other was represented by his two sons Muhammad Shams al-Dīn and Ahmad Muḥyi al-Dīn, who seem to have been allied, and their sons, including Ibrāhīm Sirāj al-Dīn b. Aḥmad Muhyi al-Dīn, the author of the second continuation of the Ta'rīkh. The rivalry may have been financial as well as political,

87 Ḥasan Tãj al-Dīn 1982: 90.

88 Ḥasan Tāj al-Dīn 1982: 91.

89 Ḥasan Tāj al-Dīn 1982: 96.

90 Ḥasan Tāj al-Dīn 1982: 99.

91 Ḥasan Tāj al-Dīn 1982: 105.

92 Ḥasan Tāj al-Dīn 1982: 107. 


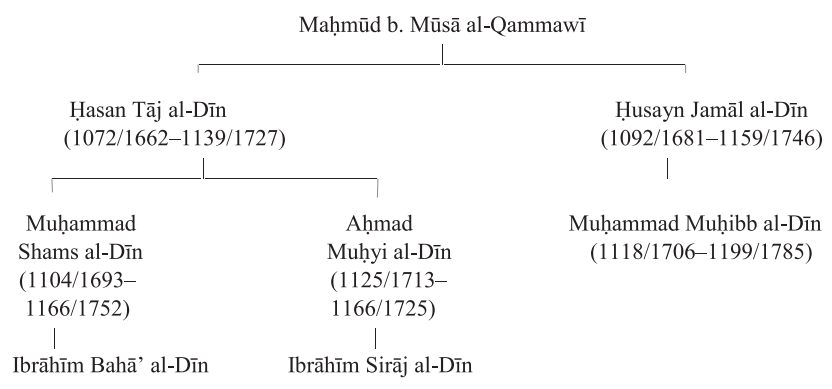

Figure 1: The family of Ḥasan Tāj al-Dīn.

for Ibrāhīm Sirāj al-Dīn comments that when Muhammad Muhibb al-Dīn died, his wealth was not distributed among his rightful heirs who included the author, Ibrāhīm Sirāj al-Dīn himself. ${ }^{93}$

The continuations of the Ta'rikh seem to voice the rivalry of these two factions, but we have no outside sources for the most part against which to balance it. There is much that is unclear to us but doubtless would have been evident to its audience. For example, the identity of the qadi during the reign of Sultan Muhammad Shams al-Dīn is never made explicit, but there are certain hints. This is also suggested in Ibrāhīm Sirāj al-Dīn's account of Sultan Muḥammad Shams al-Dīn Iskandar's takeover in 1187/1773-4 in which the new sultan "seized the books of various praiseworthy sciences from seekers of knowledge and banned anyone other than his favourite (muhibbuhu) from teaching in the Maldives." ${ }^{94}$ This may be a play on Muhammad Muhibb al-Din's name, and gives rise to the suspicion that he remained in office. This supposition is strengthened by Ibrāhīm Sirāj al-Dīn's account of the persecution of other members of the family. The author was among those who was banned from teaching and had his books confiscated, while his cousins, the descendants of Hasan Tāj al-Dīn's grandson Ibrāhīm Bahā’ al-Dīn b. Muhammad Shams al-Din had even their Qur'ans and books of fiqh taken from them. ${ }^{95}$ Yet Ibrāhīm Sirāj al-Dīn is careful to avoid attacking his relative Muhammad Muhibb al-Dīn directly, instead doing so by insinuation and suggestion. Thus while Ibrāhīm Sirāj al-Dīn's continuation may be seen in some respects as an attempt to counter the version of history propagated by Muhammad Muhibb al-Din, especially as far as his own father's role in the Malabari invasion is concerned, Muhammad Muhibb al-Dīn's chronicle is doubtless self-serving in its own ways. It concludes with the accession of Hasan 'Izz al-Dīn in 1173/1759 and an account of

93 Ḥasan Tāj al-Dīn 1982: 107.

94 Ḥasan Tāj al-Dīn 1982: 101.

95 Ḥasan Tāj al-Dīn 1982: 102-103. 
his repelling of another Malabari attack in the second year of his reign. ${ }^{96}$ Yet Muhammad Muhibb al-Dīn survived for another 25 years after this, including periods when he was not employed as qadi, and certainly would have had leisure to continue his chronicle if he had wished.

There is ample reason to be suspicious of Ibrāhīm Sirāj al-Dīn's account of events too. He was evidently as closely implicated in the politics of his day as his ancestors, replacing his enemy Mūsā Najm al-Dīn as qadi in 1201/1787. In office, he accompanied sultan Hasan Nūr al-Dīn on the pilgrimage to Mecca and Medina. On his return he was deposed in favour of Mūsā Najm al-Dīn, and exiled by the Sultan to Huvadhu Atoll. ${ }^{97}$ Under the next sultan, Muhammad Mu'īn alDīn in 1221/1806, Ibrāhīm Sirāj al-Dīn was reappointed qadi. ${ }^{98}$ Ibrāhīm Sirāj alDīn sheds little light on the reasons behind the vicissitudes of his career, but Bell notes, presumably drawing on oral sources, that the reason for his exile, "tradition confidently says [was] for dabbling in necromancy, rigidly tabooed by orthodox Muslims." 99 That such rumours were still circulating a hundred years after Ibrāhīm Sirāj al-Dīn's lifetime suggests as much about the toxic nature of Maldivian factional politics as their veracity.

\section{Conclusion}

The Ta'rīkh composed by Ḥasan Tāj al-Dīn is thus a highly complex document. On the one hand, it furnishes exemplary stories that are meant to guide its readers purportedly the sultans - as to how to conduct themselves. This purpose is not merely moralistic but also practical, for such advice is meant to provide useful tools for governance of the sultanate. The practical agenda behind the Ta'rikh is reflected in the fact that Yajima's manuscript A also contained, in addition to the histories, a collection of Maldivian “official letters”. ${ }^{100}$ Regrettably Yajima's promised third volume of his edition where this was to be published never materialised, but it seems likely the correspondence was intended as handy reference point for the sultan in conducting foreign relations, for the two examples which were published by Yajima deal with relations with the Ali Rajas of Cannanore. ${ }^{101}$ Such letters also occupy the concluding parts of Ibrāhīm Sirāj al-Dīn's

\footnotetext{
96 Ḥasan Tāj al-Dīn 1982: 86-87.

97 Ḥasan Tāj al-Dīn 1982: 108-109, 111.

98 Ḥasan Tāj al-Dīn 1982: 117.

99 Bell 2002: 41 (notes).

100 Ḥasan Tãj al-Dīn 1984: 122.

101 Ḥasan Tāj al-Dīn 1982: 127-9.
} 
continuation, ${ }^{102}$ suggesting they should not be seen as wholly separate from the historiographical tradition.

An equally if not more important purpose of the Ta'rīkh was to affirm its authors' position by denigrating their rivals and casting their own careers in the best possible light. This may have partly been aimed at the sultans, to obtain their favour and ensure each author gained, recovered or retained the coveted position of qadi; but it is likely that the audience was also fellow members of their own family and class, the ulama. What is perhaps most puzzling is not the factionalism to which the Ta'rikk gives voice, for this is well attested in Islamic historiography from other times and periods, ${ }^{103}$ but rather the fact that each of its constituent texts exists in apparent isolation, with the exception of the brief overlap between Muhammad Muhibb al-Dīn's and Ibrāhīm Sirāj al-Dīn's continuations. Did these evidently highly contentious texts really produce no reaction, at least in written form, or have these been lost along with the remainder of the Arabic literary production of the Maldives?

Such questions are ultimately unanswerable, unless new texts come to light, either in the Maldives or conceivably in the Hijaz, a place of study and exile for numerous Maldivians in pre-modern times. They do not detract from the importance of the Ta'rikk as a unique window into both the history of the Maldives and the broader Indian Ocean world, as well as the evidence it provides of an apparently thriving Arabic literary culture in the eighteenth century Maldives. They do, however, underline that as a source it must be treated with the utmost care, and every fragment of information it provides carefully evaluated in the context of what we know of its authors' lives and careers.

Acknowledgements: I am grateful to Michael Feener for comments on a draft of this paper.

\section{References}

Ahmad, Z. (1946): Contribution of Indo-Pakistan to Arabic Literature, from ancient times to 1857. Lahore: Sh. Muhammad Ashraf.

Barendse, R.J. (2002): The Arabian Seas: The Indian Ocean World of the Seventeenth Century. London: M.E. Sharpe.

Bell, H.C.P. (2002 [1940]): The Máldive Islands: Monograph on the History, Archaeology and Epigraphy. Malé: Novelty Printers and Publishers.

102 Ḥasan Tāj al-Dīn 1982: 124-6.

103 For example see Peacock 2014. 
Cummings, W. (2010): The Makassar Annals. Leiden: KITLV.

Das Gupta, A. (1979): Indian Merchants and the Decline of Surat, c. 1700-1750. Wiesbaden: Franz Steiner.

Dawlatshāh Samarqandī (1901): Tadhkirat al-Shu'arā'. Edited by E.G. Browne. London: Luzac and co.

De Somogyi, J. (1950): “Ad-Damīrīs Ḥayāt al-ḥayawān: An Arabic Zoological Lexicon”. Oriens 9: 33-43.

Feener, R.M. (ed.) (2018-2020): Maldives Heritage Survey, https://maldivesheritage.oxcis.ac.uk (last accessed 17 May 2020).

Feener, R. M. (2020): “Maldives”. Encyclopaedia of Islam. $3^{\text {rd }}$ edition.

Forbes, A.D.W. (1981): "Southern Arabia and the Islamicisation of the Central Indian Ocean Archipelagoes”. Archipel 21: 55-92.

Friedrich, R. / van den Berg, L.W.C. (1873): Codicum Arabicorum Societatis artium et scientiarum Bataviae catalogus. Batavia-Den Haag: Wijt \& Nijhoff.

Gippert, J. (2003): “Early New Persian as a Medium for Spreading Islam”. In: Persian Origins Early Judaeo-Persian and the Emergence of New Persian. Collected Papers of the Symposium, Göttingen 1999. Edited by L. Paul. Wiesbaden: Harrassowitz, 31-47.

al-Jazīrī al-Ḥanbalī, ‘Abd al-Qādir b. Muḥammad b. 'Abdallāh b. 'Abd al-Qādir b. Muḥammad al-Anșārī (2002): al-Durar al-Farā'id al-Munaz̧zama fí Akhbār al-Hajj wa-Ṭarīa Makka al-Mu'az̧zama. Edited by Muḥammad Ḥasan Muḥammad Ḥasan Ismā‘īl. Beirut: Dār alKutub al-'Ilmiyya.

Ḥasan Tāj al-Dīn (1982): Ḥasan Tãj al-Dīn's The Islamic History of the Maldive Islands with Supplementary Chapters by Muhammad Muhibb al-Dīn and Ibrāhīm Sirāj al-Dīn. Edited by Hikoichi Yajima. Vol. 1, Arabic text. Tokyo: Institute for the Study of Languages and Cultures of Asia and Africa.

Ḥasan Tāj al-Dīn (1984): Hasan Tãj al-Dīn's The Islamic History of the Maldive Islands with Supplementary Chapters by Muḥammad Muhibb al-Dīn and Ibrāhīm Sirāj al-Dīn. Edited by Hikoichi Yajima. Vol. 2, Annotations and Indices. Tokyo: Institute for the Study of Languages and Cultures of Asia and Africa.

al-Hayla, Muḥammad al-Ḥabīb (1994): al-Ta'rīkh wa'l-Mu'arrikhūn bi-Makka min al-qarn al-thālith al-hijrì ilā 'l-qarn al-thālith 'ashara. London: al-Furqan Foundation.

Kalus, L. and Guillot, C. (2005): “Inscriptions islamiques en arabe de l'archipel des Maldives”. Archipel 70: 15-52.

Kouria, M. (2017): “'Killed the Pilgrims and Persecuted Them': Portuguese Estado da India's Encounters with the Hajj in the Sixteenth Century". In: The Hajj and Europe in the Age of Empire. Edited by U. Ryad. Leiden: Brill, 14-46.

Mailaparambil, B.J. (2011): Lords of the Sea: The Ali Rajas of Cannanore and the Political Economy of Malabar (1663-1723). Leiden: Brill.

Maloney, C. (2013): People of the Maldive Islands. Hyderabad: Orient BlackSwan.

Nasheed, M. (2003): Maldives: A Historical Outline of the Traditional Dhivehi Polity 1800-1900. Malé: Orient Academic Centre.

Obeyesekere, G. (2019): Stories and Histories: Sri Lankan Pasts and the Dilemmas of Narrative Representation. Nugegoda: Sarasavi Publishers.

Peacock, A.C.S. (2014): “Court Historiography of the Seljuq Empire in Iran and Iraq: Reflections on Content, Authorship and Language”. Iranian Studies 47: 327-345.

Peacock, A.C.S. (2018): "Sufi Cosmopolitanism in the Seventeenth-Century Indian Ocean: Shari'a, Lineage and Royal Power in Southeast Asia and the Maldives". In: Challenging 
Cosmopolitanism: Coercion, Mobility and Displacement in Islamic Asia. Edited by J. Gedacht and R. M. Feener. Edinburgh: Edinburgh University Press, 53-80.

Prange, S. (2018): Monsoon Islam: Trade and Faith on the Medieval Malabar Coast. Cambridge: Cambridge University Press.

Reid, A. (1988): Southeast Asia in the Age of Commerce, 1450-1680. Vol. 1, The Lands below the Winds. New Haven: Yale University Press.

Reid, A. (1993): Southeast Asia in the Age of Commerce, 1450 1680. Vol. 2, Expansion and Crisis. New Haven, Yale University Press.

Rotter, G. (1976): Muslimische Inseln vor Ostafrika: Eine arabische Komoren-Chronik des 19. Jahrhunderts. Beirut: Steiner Verlag.

Sa‘dī (1375 AHSh): Kulliyāt-i Sa‘dī. Edited by Bahā’ al-Dīn Khurramshāhī. Tehran: Intishārāt-i Nahīd.

Safa, Z. (1989): “Bondār Rāzi”. Encyclopaedia Iranica, online edition http://www.iranicaonline. org/articles/bondar-razi-poet-in-the-4th-10th-century-

Serjeant, R.B. (1963): The Portuguese Off the South Arabian Coast: Haḍramī Chronicles. Oxford: Clarendon Press.

Thapar, R. (2013): The Past Before Us: Historical Traditions of Early North India. Ranikhet: Permanent Black.

Yajima, H. (1988): “An Arabic Manuscript on the History of the Maldive Islands”. In: Cultural Relations between East and West: Sea Routes. Edited by Prince Takihito Mihasa. Wiesbaden: Otto Harrassowitz, 71-88. 